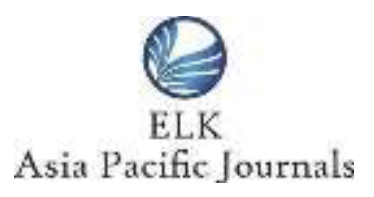

wWw.elkjournals.com

\title{
CRITERIA FOR EVALUATION OF ALTERNATIVES IN ONLINE CONSUMER DECISION MAKING PROCESS
}

\author{
DR. OLY MISHRA \\ Assistant Professor, \\ School of Management Studies, \\ Gayatri Vidya Parishad College for Degree and PG Courses, \\ Andhra University, \\ India \\ olymishra@gmail.com
}

\begin{abstract}
Recently there has been a rapid increase in the tendency of customers to shop online. The change in the socio-economic conditions and the lifestyle of people has led to this change. The online shopping process has some pros and cons. The major advantage of online shopping is that there are a wide variety of products from which the online consumers can choose. The availability of wide variety makes it difficult for the consumers to choose. The buying decision process includes five stages i.e. need recognition, information search, evaluation of alternatives, purchase decision and post-purchase behavior. The evaluation of alternatives becomes more complicated when the purchase has to be done online. The online consumers will have to collect information from many sources and evaluate the different alternatives based on different criteria. The evaluation of alternatives is an important component of the consumers' decision making process. The aim of this paper is to analyze the different criteria for evaluation of alternatives used by online consumers. A survey was conducted on 856 young Indian consumers who have been purchasing durable products through online shopping websites. 11 criteria for evaluation of alternatives were identified. The responses to the survey were used to find out the frequency of the evaluation of alternatives based on these criteria by the respondents. The 11 criteria for evaluation of alternatives were grouped together into three major categories of evaluation of alternatives using Factor Analysis. The paper also suggests marketing strategies to e-tailers based on the three major categories of evaluation of alternatives.
\end{abstract}

Keywords: Consumers' Decision Making Process, Evaluative Criteria, Evaluation of Alternatives, Online Consumers.

\section{INTRODUCTION}

Many researchers have tried to understand the consumers' mind in spite of the fact that human mind is difficult to understand. Since time immemorial, companies have been trying to understand the consumers' mind so that they can plan their marketing strategies accordingly. The aim of such kind of research was to understand the 
consumers' purchase decision making process and to explain the consumer behaviour. Some of the important models of consumer purchase decision making process that have been developed are: Nicosia model, Howard-Sheth model and EBM model. These models provide useful insights into the consumers' mind and help to understand the purchase decision (Howard, 1989).

The earliest purchase decision making model was developed by Engel, Kollat and Blackwell and it was known as EKB Model (Engel et al., 1968). This was the basic model which was used by many marketing researchers to develop better models that provided a better picture about the consumers' purchase decision making process. Among the different models that have been developed, the most widely accepted model is the EBM model or Engel Blackwell Miniard model (Engel et al., 1995).

In this study, the EBM model of consumer purchase decision making process has been considered. The reason for selecting this decision making model over the other models is that it is a coherent process which assumes a consumer to be a rational person. In other words, he/she thinks in a logical manner. Moreover, the process does not end with purchase of the product; instead it ends with the post-purchase behaviour. This is another positive aspect of the model. The post-purchase behaviour is either satisfaction or dissonance. The EBM model of consumers' online purchase decision making process states that a consumer passes through five stages in the decision making process. They are: Need Recognition, Information Search, Evaluation of Alternatives, Purchase and Post Purchase. The first three stages i.e. Need Recognition, Information Search and Evaluation of Alternatives, are together called the Pre-Purchase stage of consumers' online purchase decision making process. The Pre-Purchase stage is when the consumer recognizes their need for a particular product and searches for information in order to fulfil the need. Finally the best alternative is selected after comparing and evaluating the various alternatives. Evaluation involves bringing together and analyzing the information that has been collected in the information search stage (Gay et al, 2010). From the several sources of information search an online consumer finds several alternatives, that may fulfil his/her need. This is a crucial stage as it will finally lead to taking the purchase decision.

In the context of online shopping, the real challenge for the consumer is to collect information and evaluate the various 
alternatives. There are several varieties of products as well as several variations in the same brand that have the capacity to fulfil the consumers' need (Solomon, 2004). In such a situation, the consumer has to decide which product to purchase based on certain criterion. This is known as evaluative criteria. The evaluative criteria are based on several attributes or benefits expected from the product by the consumer. In other words, Evaluative criteria are the standards based on which the consumer differentiates amongst the different varieties of products or brands. The different alternatives may be evaluated either based on objective features or subjective features. Objective features include the functional or the utilitarian aspects of the product like attributes of the product, benefits obtained from the product etc. On the other hand subjective features relate to the emotional or the hedonic aspects related to the product like status, convenience, privacy, security of transaction etc.

Consumers purchasing a product for the first time carefully evaluate several varieties of the product while consumers making a habitual decision may not consider many alternatives. Extended evaluation of alternatives also takes place when the consumer faces conflict among the various alternatives of products available to him (Solomon, 2004).

\section{OBJECTIVES OF THE PAPER}

The objectives of the paper are

- To understand the criteria for

Evaluation of Alternatives in consumers' Online purchase decision making process.

- To group the criteria for Evaluation of Alternatives into lesser number of categories.

\section{METHODOLOGY}

For the purpose of the study, Primary data and Secondary data was collected. Primary data was collected through a questionnaire. The questionnaire was distributed among 1000 people of Visakhapatnam city of Andhra Pradesh through e-mail and also by meeting them personally. Among them only 870, responses were complete and 856 responses were found suitable for the study. The secondary data is collected from books, journals, newspapers etc. The questionnaire consists of 5-point Likert scale. The frequency of criteria for Evaluation of Alternatives are measured on a scale of 1 to 5 , where 1 is for 'Never', 2 is for 'Sometimes', 3 is for 'Occasionally', 4 is for 'Frequently' and 5 is for 'Always'. The age group of the respondents varies from 18 - 40 years. Judgmental sampling approach has been 
followed to select the respondents of the study and the criterion for selecting the respondents was that they must shop for durable products online frequently. The internal consistency and reliability of the scales used in the questionnaire were checked by calculating the Cronbach Alpha. The Cronbach Alpha value is 0.773 which implies that the variables taken for the study are reliable. The collected data was tabulated. The Mean and Standard Deviation of the various criteria for Evaluation of Alternatives was calculated and then Factor Analysis was conducted in order to group the 11 criteria for Evaluation of Alternatives into a lesser number.

\section{DATA ANALYSIS}

There are several criteria that the online shopping consumers take into consideration before they purchase a product online. The evaluative criteria that have been taken in this study are Price of the product, Quality of product, Brand Name, Discounts and Deals, Offers on the product, Ease of Transaction, Consumer Reviews, Secure Mode of Payment, Past online shopping experience, Trustworthiness of online shopping websites and Discussion with family and friends.
The respondents' frequency of using different sources to evaluate alternatives before purchasing a product online, are presented in Table 1.

\subsection{Evaluation of alternatives based on Price of product - Respondents' Opinions}

Price is one of the important criteria used for evaluation of alternatives. Consumers form opinions about the company, products and brands based on the price offered. One of the most commonly prevalent beliefs of the consumers is the price-quality relationship. Novice consumers believe that price is the only relevant product attribute to evaluate the various alternatives.

Among the selected respondents, about two percent of the respondents 'never' evaluate their alternatives based on price, about 10 percent 'sometimes' evaluate, about 13 percent 'occasionally' evaluate, about 25 percent evaluate 'frequently' and about 50 percent of the respondents 'always' evaluate the alternatives based on price. Thus, it can be concluded that almost 50 percent of the respondents 'always' evaluate the alternatives based on price of the product.

4.2 Evaluation of alternatives based on Quality of product - Respondents' Opinions 
Quality of the product is another important criterion for evaluating the various alternatives of a consumer. Often price of the product and the quality of the product are closely related to each other. Generally consumers consider price as an external attribute that helps the consumers to make judgment about the product quality (Pechmann and Ratneshwar, 1991). However, when consumers have the ability to process other cues that help in understanding product quality, then they are less likely to use price as an indicator of quality (Rao and Monroe, 1988).

Of the 856 respondents, about one percent 'never' evaluate their alternatives based on quality of product, about eight percent 'sometimes' evaluate, about six percent 'occasionally' evaluate, 29 percent 'frequently' evaluate and about 55 percent 'always' evaluate their product alternatives based on quality. Thus, it can be concluded that more than half of the respondents 'always' evaluate their product alternatives based on quality before taking the decision to purchase online.

\subsection{Evaluation of alternatives based on}

Brand Name - Respondents'
Opinions

Brand also plays a major role as an evaluative criterion when a consumer wants to purchase a product online. One of the most common ways of simplifying the decision making process is by selecting and staying loyal to a particular brand. In this case, the consumer can spend less time on the information search and evaluation of alternatives stages. The consumer can directly take the decision to purchase the product of the brand that they prefer. Brands are a significant evaluative criterion as consumers identify themselves with the brand personality (Aaker and Kevin, 1990).

Companies believe that by creating a strong brand image in the minds of the consumers, they can reduce the uncertainty faced by the consumer while evaluating various alternatives. This also increases the brand loyalty of the consumer and the possibility of purchasing the brand increases. A brand name is not only a name or a symbol but also a differentiator of the company from its rivals and competitors (Collins-Dodd and Lindley, 2003). As consumers are not able to examine the product personally in online shopping so consumers are likely to take purchase decision based on recognizable cues like Brand Name (Huang et al., 2004; Park and Stoel, 2005). For habitual purchases, 
a consumer may not evaluate several brands and eventually purchase the brand that he/she prefers or is familiar with. However, when consumer is purchasing a product for the first time then they will compare and contrast the different brands that are available.

From the 856 respondents, about five percent 'never' evaluate alternatives based on the brand name, about six percent evaluate 'sometimes', about 23 percent evaluate 'occasionally', about 20 percent evaluate 'frequently' and about 47 percent 'always' evaluate alternatives based on the Brand Name before purchasing it online. Thus, almost half of the respondents 'always' evaluate alternatives based on the brand name.

\subsection{Evaluation of alternatives based on \\ Discounts and Deals - Respondents' Opinions}

The discounts and deals provided by the e-tailers are other important criteria for evaluating alternatives. It is one of the most attractive factors in online shopping. Some online consumers emphasize on the enjoyment of looking out for discounts on various products before purchasing any product. This is known as Value shopping (Arnolds \& Reynolds, 2003). Among the different Personality types, Extroverts enjoy shopping for bargains and discounts as they find searching for deals and discounts exciting and thrill-seeking (Gray, 2007). Provision of deals and discounts influences the shopping value in the consumers' mind. Due to deals and discounts, the consumers feel that they have bargained which leads to creating "transaction utility" or "smart shopper feelings". This leads to increasing hedonic value. In addition to this, deals and discounts can create utilitarian value also as it may lead to purchasing an efficient end product (Babin et al., 1994).

Of the total respondents, about 11 percent 'sometimes' evaluate product alternatives based on Discounts and Deals, about 19 percent evaluate 'occasionally', about 34 percent evaluate 'frequently' and about 36 percent 'always' evaluate their alternatives based on Discounts and deals before purchasing a product online. An interesting point to be noted here is that none of the respondents has selected 'never'. In other words, all respondents have used discounts and deals as an evaluating criterion in varying frequencies before purchasing a product online. The sum total of the respondents who 'frequently' and 'always' evaluate alternatives based on discounts and deals is 70 percent.

\subsection{Evaluation of Alternatives based on} Offers - Respondents' Opinions 
Offers are one of the promotional strategies of the e-tailers so that they can attract more number of consumers to purchase their products. In the context of online shopping, offers are a crucial factor. It has been found that offers are one of the main reasons which lead to impulse buying by the consumers of super markets (Muruganantham \& Bhakat, 2013). Offers are mostly short term marketing tools that are designed in such a way that they attract the attention of the consumers (Bhandari, 2012) and stimulate them to purchase in large quantities of a product in a short period of time (Kotler at.el., 2013). The intention is to produce quick and short term changes in consumers' buying behaviour (Nagadeepa, et al., 2015). Some commonly prevalent types of offers are: Rebate (provide price reduction after purchase), Coupons, Price packs (to attract brand switchers, who are primarily looking for low price), Contests (to increase the repurchase rate of occasional customers), Premium/gifts (offer at low cost or free as an incentive to purchase) etc.

Among the 856 respondents, about two percent 'never' evaluate their alternatives based on offers on the product before purchasing it online, about nine percent 'sometimes' evaluate, about 21 percent 'occasionally' evaluate, about 25 percent 'frequently' evaluate and 43 percent 'always' evaluate their alternatives based on 'offers on the product' before purchasing it online. Thus, it is inferred that the sum total of the number of respondents who 'frequently' and 'always' evaluate their alternatives based on offers on the product before purchasing it online is about 70 percent of the sample respondents.

\subsection{Evaluation of Alternatives based on \\ Ease of Transaction - Respondents' Opinions}

The ease of transaction is important for online consumers to complete their purchase. So it is given a lot of importance in the evaluation of alternatives. If the Online shopping process is complicated then it will create frustration in the minds of the online consumers. If online consumers cannot complete the transaction in a reasonable amount of time then they will lose confidence and will abandon the purchase process (Bhatti et al., 2000). If the online consumers find it difficult to carry out the transaction then they may not come back to the online shopping web site. Therefore, a transaction must be easy to retain the online consumers of the e-tailer.

Out of the 856 respondents, about four percent of the sample respondents 
'never' evaluate the alternatives based on the ease of transaction, about 10 percent 'sometimes' evaluate, about 21 percent 'occasionally' evaluate, about 24 percent 'frequently' evaluate and about 42 percent 'always' evaluate the alternatives based on the ease of transaction. Thus it can be said that the total of the number of respondents who 'frequently' and 'always' evaluate the alternatives based on the ease of transaction is almost 65 percent of the sample respondents.

\subsection{Evaluation of Alternatives based on Consumer Reviews - Respondents' Opinions}

When a consumer is evaluating the various alternatives before purchasing the product, then he/she looks for information about the attributes of the product as well as about the experience of using the product. The information about the attributes of the product is given by the e-tailer while the information about the experience of using the product is given by consumer reviews. In other words, consumer reviews provide customer oriented information i.e. measuring product performance as a user, and e-tailer provides product oriented information i.e. product attributes, technical specifications etc. (Bickart and Schindler, 2001). Online consumer reviews also act as a recommender to the other consumers of the product. It can be considered as a form of word-of-mouth promotion. Recent studies show that online consumer reviews significantly impact product sales (e.g., Chen, Wang, and Xie 2011; Chevalier and Mayzlin 2006; Liu 2006).

Among the selected respondents, about one percent 'never' evaluate their alternatives based on consumer reviews, about 11 percent 'sometimes' evaluate, about 20 percent 'occasionally' evaluate, about 24 percent 'frequently' evaluate and about 44 percent 'always' evaluate their alternatives based on 'consumer reviews' before purchasing a product online. Thus, nearly half of the respondents 'always' evaluate alternatives based on consumer reviews.

\subsection{Evaluation of Alternatives based on Secure Mode of Payment - Respondents' Opinions}

Online shopping websites have to offer a wide variety of payment options like Debit card, Credit card, Cash of Delivery, Net banking. Most of the online consumers fear sharing financial information online and hence they do not trust the website for secure payments. There are a number of risks and benefits associated with online shopping. These risks prevent some consumers from 
buying products online especially high priced items, items that require visual inspection etc. The Internet and online shopping websites have been subjected to legislative actions regarding financial crime, frauds, consumer protection, consumer privacy and content (Rapp, 1997). In order to prevent these crimes and to protect the interests of the consumers, new technology has been developed for encryption and secure transaction. The growth of secure payment mechanisms through Pay pal, Veri Sign etc have contributed to a substantial reduction in the risks associated with online payments.

From the 856 respondents, about one percent of the respondents 'never' evaluate their alternatives based on secure mode of payment, about seven percent 'sometimes' evaluate, about 20 percent 'occasionally' evaluate, about 19 percent 'frequently' evaluate and about 53 percent 'always' evaluate their alternatives based on secure mode of payment. Thus, it can be said that more than half of the respondents 'always' evaluate their alternatives based on secure mode of payment.

\subsection{Evaluation of Alternatives based on}

Past online shopping Experience Respondents'Opinions
Past online shopping experience of consumers is an influential factor that affects the purchase decision making process of online consumers. It creates confidence in the minds of the online consumers and they find online shopping reliable. Previous research shows that customers' past online experience is a strong determinant of their online shopping behavior (Yoh et al., 2003). Moreover, it has also been found that the past online purchasing experience has a strong correlation with the intention to purchase online (Ranganathan and Jha, 2007). Consumers' intention to purchase online is related to his/her past online shopping experience and has a direct effect on the behavior of online consumers (Monsuwe et al., 2004). Etailers can improve their service standards by knowing about the past online shopping experience of buyers.

Of the total respondents, about three percent of the sample respondents 'never' evaluate the alternatives based on 'past online shopping experience', about seven percent of the respondents 'sometimes' evaluate, about 19 percent 'occasionally' evaluate, about 14 percent 'frequently' evaluate and about 60 percent 'always' evaluate their alternatives based on the 'past online shopping experience'. Thus, almost 60 
percent of the respondents always evaluate their alternatives based on the 'past online shopping experience'.

\subsection{Evaluation of Alternatives based}

on Trustworthiness of online shopping website - Respondents'

\section{Opinions}

The trustworthiness of the online shopping website affects the reliability of the e-tailers. This was one of the main conclusions drawn in the report of the PEW Internet \& American Life Project (Horrigan, 2008). Although online shopping has become part of everyday life, many consumers are still afraid of negative experiences due to lack of trustworthiness. It is important for consumers to be able to judge the trustworthiness of the online shopping website. Some of the factors that increase the trustworthiness of the online shopping websites are perceptions about the company, perceptions about the website, and consumer characteristics (McKnight et al. 2002; Koufaris and Hampton-Sosa 2004; Metzger 2006). It is therefore important for the online shopping websites to signal trustworthiness and attract consumers (Riegelsberger et al. 2005).

Among the 856 respondents, about four percent of the respondents 'never' evaluate their alternatives based on trustworthiness of online shopping websites, about seven percent 'sometimes' evaluate, about 14 percent 'occasionally' evaluate, about 24 percent 'frequently' evaluate and about 51 percent 'always' evaluate their alternatives based on trustworthiness of the online shopping website. Thus, almost 75 percent of the respondents evaluate their alternative based on the trustworthiness of the online shopping website.

\subsection{Evaluation of Alternatives based on Discussion with family and friends - Respondents' Opinions}

Family has always played an important role in the life of individuals in India. Mostly word-of-mouth is sought and received from individuals who are trusted by the consumer, such as family and friends (Bansal and Voyer, 2000; Brown and Reingen, 1987). Consumers generally rely more on the information given by their family and friends. Hence, the discussion with family and friends helps in evaluation of alternatives when a consumer has to purchase a product online. Some consumers purchase only the brands that they have used in their family. This has been established especially for domestic products (Coupland 2005). The inexperienced person has to be "confident in and 
willing to act on the basis of the words, actions and decisions of another" (Das \& Teng, 2004). In other words, when a consumer is not confident purchasing products online then he/she acts based on the guidance given by his/her family or friends who is well-experienced in online shopping.

Among the selected respondents, about seven percent 'never' evaluate their alternatives based on discussion with family and friends, 15 percent 'sometimes' evaluate, about 25 percent 'occasionally' evaluate, about 18 percent 'frequently' evaluate, and about 36 percent 'always' evaluate their alternatives based on discussion with family and friends. Thus, more than onethird of the respondents 'always' evaluate their alternatives based on discussion with family and friends.

\subsection{Mean and Standard deviation of criteria for Evaluation of alternatives:}

The Mean and the Standard Deviation of the criteria used by the respondents for evaluation of alternatives is calculated and presented in Table 2 to find out which criteria are most frequently used and which criteria are least frequently used.

It can be seen from the table that the highest mean is for 'Quality of Product' while the least mean is 'Discussion with family and friends'. This implies that most of the respondents evaluate the different alternatives based on 'Quality of the product' and least number of respondents evaluate alternatives based on 'Discussion with family and friends'. The highest Standard Deviation is for 'Discussion with family and friends' while the least Standard Deviation is for 'Quality of the product'. This implies that most of the respondents differ in their frequency of evaluating alternatives based on 'Discussion with family and friends' while least number of respondents differs in their frequency of evaluating alternatives based on 'Quality of the product'.

\subsection{Factor Analysis of Criteria for}

\section{Evaluation of Alternatives:}

The study considered 11 criteria for Evaluation of Alternatives with regard to purchasing a product online. These criteria have been subjected to Factor Analysis so that they can be reduced to based on their correlations. Varimax Rotation has been used and the coefficient below 0.50 have been suppressed from being displayed.

Table 3 presents that the Kaiser-MeyerOlkin measure of sampling adequacy for the criteria for Evaluation of alternatives is 0.873 which is above the recommended value of 0.6 , and Bartlett's 
test of sphericity is significant $\left(\chi^{2}(55)=\right.$ 4524.003, $p<0.05)$. This implies that the sampling technique and sampling distribution are suitable for Factor Analysis.

Table 4 provides the Communalities for the criteria for evaluation of alternatives. It shows that the communalities are all above 0.3 , further confirming that each item shares some common variance with other items.

Table 5 shows the Total variance of criteria for evaluation of alternatives. The initial Eigen values showed that the first factor explained 47 percent of the variance, the second factor 12 percent of the variance, and a third factor eight percent of the variance. The three factors that were extracted have a total variance of 68.023 i.e. these factors explain 68 percent of the variance.

Figure 2 is a scree plot of Eigen values against all the criteria for evaluation of alternatives. The chart shows that the curve begins to flatten from component 4 and the Eigen value is less than 1. Hence, only three factors can be retained

Table 6 shows that there are five criteria for Evaluation of Alternatives in the $1^{\text {st }}$ factor, four criteria for Evaluation of Alternatives in the $2^{\text {nd }}$ factor and two criteria for Evaluation of alternatives in the $3^{\text {rd }}$ factor. The $1^{\text {st }}$ factor is named as Basic Product related criteria for
Evaluation of Alternatives, $2^{\text {nd }}$ factor is named as Additional Product related criteria for Evaluation of Alternatives and $3^{\text {rd }}$ factor is named as Non-product related criteria for Evaluation of Alternatives.

Ease of Transaction (0.594), Consumer Reviews (0.718), Secure mode of payment (0.717), Past online shopping experience (0.830), Trustworthiness of online shopping website (0.761) and Discussion with family and friends (0.765) are together categorized as the Non-Product related criteria for Evaluation of Alternatives category. Brand Name (0.653), Discounts and Deals (0.834), and Offers (0.866) are together categorized as the Additional Product-related criteria for Evaluation of Alternatives. Price of Product (0.917) and Quality of Product (0.592) are categorized as Basic Product related criteria for Evaluation of Alternatives. Thus, the Factor analysis on the 11 criteria for evaluation of alternatives gives three main categories of criteria for Evaluation of Alternatives.

\section{FINDING AND SUGGESTIONS}

Among the 856 respondents selected for the study, about 50 percent of the respondents 'always' evaluate the various product alternatives based on Price of the Product, about 25 percent 
ELK ASIA PACIFIC JOURNAL OF MARKETING \& RETAIL MANAGEMENT

ISSN 2349-2317 (Online); DOI: 10.16962/EAPJMRM/issn. 2349-2317/2018; Volume 9 Issue 4 (2018)

'frequently', about 13 percent 'occasionally', about 10 percent 'sometimes' and about two percent 'always' evaluate the various product alternatives based on Price of the Product.

More than half of the respondents 'always' evaluate the product alternatives based on Quality of the product before taking the decision to purchase online followed by about one-third of the respondents who 'frequently' evaluate their product alternatives based on quality.

Almost half of the respondents 'always' evaluate alternatives based on the Brand Name followed by about one-fourth of the respondents who 'occasionally' evaluate alternatives based on the Brand Name before purchasing it online.

All respondents have used Discounts and deals as an evaluating criterion in varying frequencies before purchasing a product online. It is found that about 70 percent of the respondents evaluate the products based on Discounts and deals.

The sum total of the number of respondents who 'frequently' and 'always' evaluate the product alternatives based on Offers on the product before purchasing it online are about 70 percent of the sample respondents

The total of the number of respondents who 'frequently' and 'always' evaluate the alternatives based on the Ease of transaction is almost 65 percent of the sample respondents. Almost 70 percent of the sample respondents evaluate their alternatives based on Consumer reviews.

More than half of the respondents 'always' evaluate the alternatives based on Secure mode of payment, while almost the same percentage of respondents 'occasionally' and 'frequently' evaluate the alternatives based on Secure mode of payment.

Almost 60 percent of the respondents 'always' evaluate their alternatives based on the Past online shopping experience and 75 percent of the respondents 'more than occasionally' evaluate the alternatives based on the Trustworthiness of the online shopping website. More than one-third of the respondents 'always' evaluate the alternatives based on Discussion with family and friends.

Most of the respondents evaluate the different product alternatives based on Quality of the product and a very low percentage of respondents evaluate their 
ELK ASIA PACIFIC JOURNAL OF MARKETING \& RETAIL MANAGEMENT

ISSN 2349-2317 (Online); DOI: 10.16962/EAPJMRM/issn. 2349-2317/2018; Volume 9 Issue 4 (2018)

alternatives based on Discussion with family and friends.

Based on the Means and Standard Deviations of the various Sources of Information Search, it is observed that most of the respondents differ in their frequency of evaluating alternatives based on Discussion with family and friends while a least number of respondents differ in their frequency of evaluating alternatives based on Quality of the product.

Using Factor Analysis, the eleven criteria for Evaluation of Alternatives has been reduced into three broad categories. They are Basic Product related criteria, Additional Product related criteria and Non-product related criteria. The Price of the Product and Quality of the Product have been grouped together as 'Basic Products related criteria for Evaluation of Alternatives', as these are the essential and fundamental characteristics of the product that are considered by the consumer when they evaluate various product alternatives. The Brand name, Discounts and deals and Offers are together called as 'Additional Product related criteria for Evaluation of Alternatives'. These are supplementary criteria that are related to the product which are used for evaluating alternatives by the consumers. The Ease of Transaction, Consumer Reviews, Secure mode of payment, Past online shopping experience, Trustworthiness of online shopping websites and Discussion with family and friends are grouped together as 'Non-product related criteria for Evaluation of Alternatives'.

\section{CONCLUSION}

The pre-purchase stage of online consumer's purchase decision making process includes three sub-stages i.e. need recognition, information search and evaluation of alternatives. Among these three sub-stages, the evaluation of alternatives is the most crucial stage. It leads to the purchase stage of the consumers' decision making process. A person may evaluate the alternatives of a product based on several criteria like price, quality of the product, discounts and offers etc. These evaluative criteria can be broadly listed as Basic Product related criteria for Evaluation of Alternatives, Additional Product related criteria for Evaluation of Alternatives and Non-product related criteria for Evaluation of Alternatives.

So, the e-tailer should be able to give the customers the advantages in criterion which is given more importance by the customer. The evaluation of alternatives 
of the respondents is mostly based on the quality of products and the discussion with family and friends. Thus, e-tailers should design their marketing strategies in such a way that the consumers should purchase the product after evaluating the various alternatives.

\section{REFERENCES}

[1] Aaker, David A., \& Keller, Kevin L. (1990). Consumer Evaluations of Brand Extensions. Journal of Marketing, 54, .27 - 41.

[2] Arnold, M., \& Reynolds, K. (2003). Hedonic Shopping Motivations. Journal of Retailing, 79, 77 - 95.

[3] Babin, B.J., Darden, W.R., \& Griffin, M. (1994). Work and/or Fun: Measuring Hedonic and Utilitarian Shopping Value. Journal of Consumer Research, $20,644-656$.

[4] Bhandari, P. (2012). A Study On Impact Of Sales Promotional Activities On Customer Buying Behaviour With Special Reference To Rathi Build Mart, Raipur. International Journal of Science And Research. 17, 187 198.
[5] Bickart, B., \& Schindler, R.M. (2001). Internet forums as influential sources of consumer information. Journal of Interactive Marketing, 15, 31 40.

[6] Brown, J. J., \& Reingen, P. H. (1987). Social Ties and Word-ofMouth Referral Behavior. Journal of Consumer Research, $14,350-362$.

[7] Chen, Y., Wang, Q., \& Xie, J., (2011). Online Social Interactions: A Natural Experiment on Word of Mouth versus Observational Learning. Journal of Marketing Research, $28,276-289$.

[8] Chevalier, J., \& Dina Mayzlin, (2006). The Effect of Word of Mouth on Sales: Online Book Reviews. Journal of Marketing Research, 25, 345 - 354.

[9] Collins-Dodd, C. \& Lindley, T., (2003). Store brand and retail differentiation: the influence of store image and store brand attitude on store own brand perceptions. Journal of Retailing and Consumer Services, 10, 345 352. 
[10] Engel, J.F., Blackwell, R.D., \& Miniard, P.W., (1995). Consumer behaviour, 8th ed. Fort Worth: Dryden Press.

[11] Engel, J.F., Kollat, D.T., \& Blackwell, R.D., (1968). Consumer behaviour. New York: Holt, Rinehart and Winston.

[12] Gay, R., Charlesworth., \& Esen, R. (2010). Online Marketing: a customer-led approach. Oxford University Press Inc, New York.

[13] Gray, P. (2007). Psychology. Boston College, $5^{\text {th }}$ Edition, Worth Publishers.

[14] Horrigan, J. B. (2008). Online shopping: Internet users like the convenience but worry about the security of their financial information, PEW Internet \& American Life Project.

[15] Howard, J. A. (1989). Consumer behaviour in marketing strategy. Englewood Cliffs, NJ: PrenticeHall.

[16] Huang, W., Schrank, H. \& Dubinsky, A., (2004). Effect of brand name on consumers' risk perceptions of online shopping,Journal of Consumer Behavior, 4, 40 - 50.
[17] Kotler K.,Keller K.L., Koshy A., Jha M.(2013), Marketing Management, Pearson Education Inc, Prentice Hall, India.

[18] Koufaris, M., \& Hampton-Sosa, W., (2004). The development of initial trust in an online company by new customers. Information \& Management, 41, 377 - 397.

[19] Liu, Y., (2006). Word of Mouth for Movies: Its Dynamics and Impact on Box Office Revenue, Journal of Marketing, 70, 74 - 89.

[20] McKnight, D. H., Choudhury, V., \& Kacmar, C., (2002) Developing and validating trust measures for e-commerce: an integrative typology. Information Systems Research Special Issue: Measuring e-Commerce in NetEnabled Organizations, 13, 334 359.

[21] Metzger, M. J., (2006). Effects of site, vendor, and consumer characteristics on web site trust and disclosure. Communication Research, Vol. 33, 155 - 179.

[22] Muruganantham, G. \& Bhakat, R. S., (2013). A Review Of Impulse Buying Behaviour. International 
Journal of Marketing Studies, Vol.13, $150-156$.

[23] Nagadeepa, C., Selvi, J. T. \& Pushpa., A., (2015). Impact Of Sale Promotion Techniques On Consumers' Impulse Buying Behaviour Towards Apparels At Bangalore. Asian Journal of Management Sciences \& Education, 4, 117 - 130.

[24] Park, J. \& Stoel, L., (2005) Effect of brand familiarity, experience and information on online apparel purchase, International Journal of Retail \& Distribution Management, 33, 148 - 160.

[25] Pechmann, C., \& Ratneshwar, S., (1991). The Use of Comparative Advertising for Brand Positioning: Associate Versus Differentiation, Journal of Consumer Research, 18, 145-160.

[26] Ranganathan, C. and Jha, S., "Examining online purchase intentions in $\mathrm{B} 2 \mathrm{C}$ ecommerce: testing an integrated model", Information Resources Management Journal, 2007, 20, $48-64$.
[27] Rao, A. R., \& Monroe, K. B., (1988). The Moderating Effect of Prior Knowledge on Cue Utilization in Product

Evaluations, Journal of Consumer Research, 15, 45 - 52.

[28] Rapp, J.B., (1997). Electronic commerce: a Washington perspective, Readings in Electronic Commerce. AddisonWesley, Reading, MA.

[29] Riegelsberger, J., Sasse, M. A., \& McCarthy, J. D., (2005) The mechanics of trust: a framework for research and design. International Journal of HumanComputer Studies, 62, 381 - 422.

[30] Solomon, M., (2004). Consumer Behavior: Buying, Having and Being, $6^{\text {th }}$ Edition, FT Prentice Hall Upper Saddle River, N.J.

[31] Yoh, E., Damhorst, M., Sapp, S., \& Laczniak, R., (2003). Consumer adoption of the Internet: The case of apparel shopping. Psychology \& Marketing, 20, 1095-1118. 
ELK ASIA PACIFIC JOURNAL OF MARKETING \& RETAIL MANAGEMENT

ISSN 2349-2317 (Online); DOI: 10.16962/EAPJMRM/issn. 2349-2317/2018; Volume 9 Issue 4 (2018)

\section{LIST OF FIGURES}

Figure 1

Engel Blackwell Miniard model of consumer purchase decision making process 


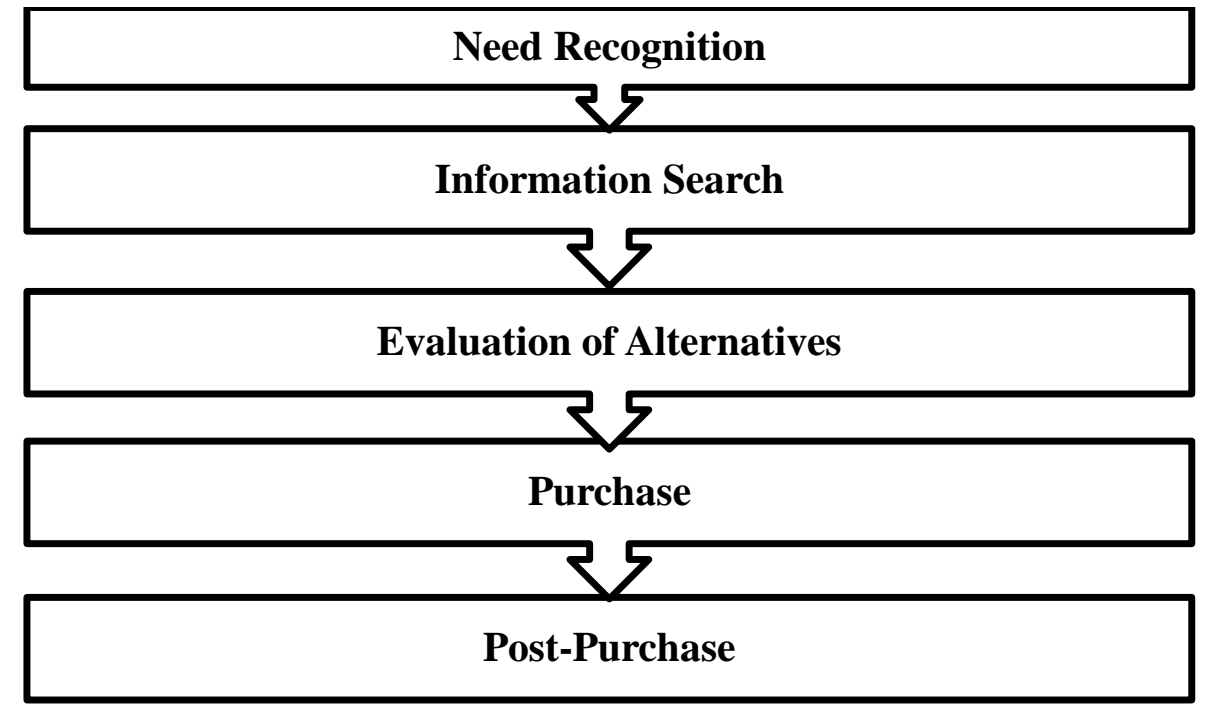

Figure 2

Scree Plot of criteria for Evaluation of Alternatives

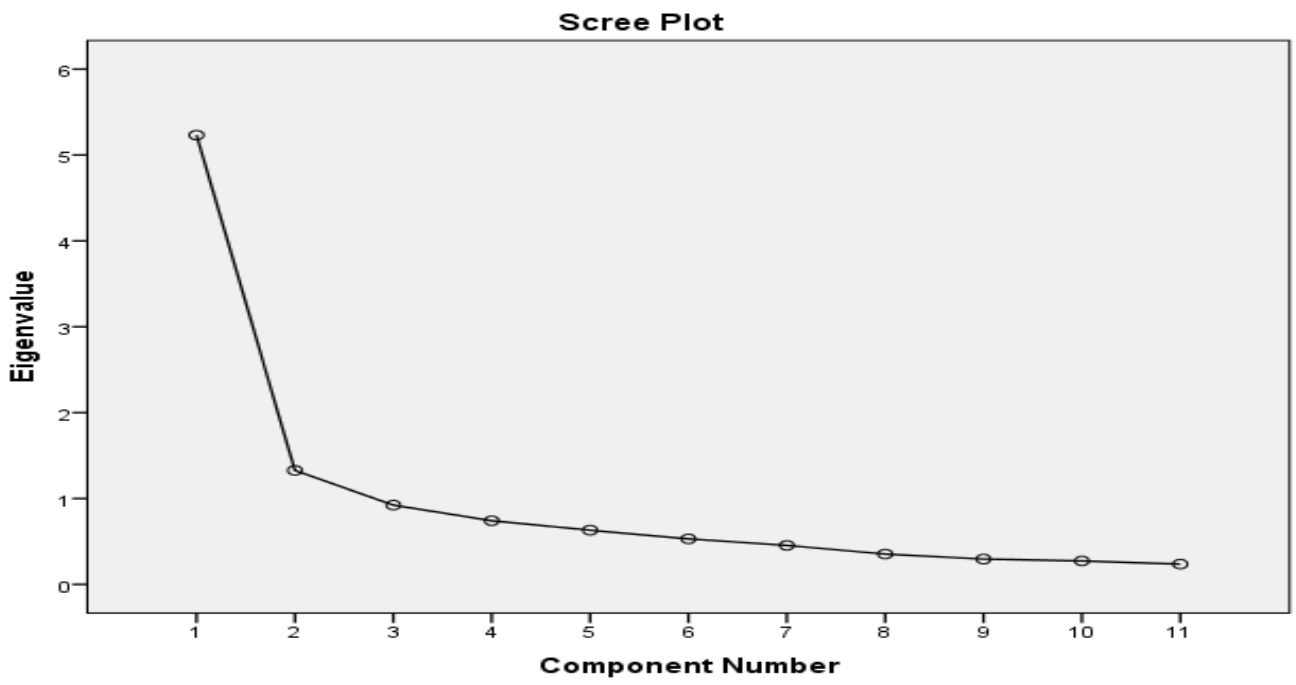

\section{LIST OF TABLES}


Table: 1

Evaluative Criteria of Respondents

\begin{tabular}{|c|c|c|c|}
\hline Evaluative Criteria & $\begin{array}{l}\text { Frequen } \\
\text { cy }\end{array}$ & $\begin{array}{l}\text { Number of } \\
\text { Respondents }\end{array}$ & $\begin{array}{l}\text { Percent } \\
\text { age }\end{array}$ \\
\hline $\begin{array}{l}\text { Evaluation of Alternatives based on Price of } \\
\text { product }\end{array}$ & $\begin{array}{l}\text { Never } \\
\text { Sometim } \\
\text { es } \\
\text { Occasion } \\
\text { ally } \\
\text { Frequentl } \\
\text { y } \\
\text { Always }\end{array}$ & $\begin{array}{l}16 \\
88 \\
112 \\
216 \\
424\end{array}$ & $\begin{array}{r}1.9 \\
10.3 \\
13.1 \\
\\
25.2 \\
49.5\end{array}$ \\
\hline $\begin{array}{l}\text { Evaluation of Alternatives based on Quality } \\
\text { of product }\end{array}$ & $\begin{array}{l}\text { Never } \\
\text { Sometim } \\
\text { es } \\
\text { Occasion } \\
\text { ally } \\
\text { Frequentl } \\
\text { y } \\
\text { Always }\end{array}$ & $\begin{array}{c}8 \\
72 \\
56 \\
248 \\
472\end{array}$ & $\begin{array}{l}0.9 \\
8.4 \\
6.5\end{array}$ \\
\hline $\begin{array}{l}\text { Evaluation of Alternatives based on Brand } \\
\text { Name }\end{array}$ & $\begin{array}{l}\text { Never } \\
\text { Sometim } \\
\text { es } \\
\text { Occasion } \\
\text { ally } \\
\text { Frequentl } \\
\text { y } \\
\text { Always }\end{array}$ & $\begin{array}{r}40 \\
48 \\
200 \\
\\
168 \\
400\end{array}$ & $\begin{array}{l}23.4 \\
19.6 \\
\mathbf{4 6 . 7}\end{array}$ \\
\hline Evaluation of Alternatives based on & Never & 0 & 0 \\
\hline
\end{tabular}




\begin{tabular}{|c|c|c|c|}
\hline Discounts and Deals & $\begin{array}{l}\text { Sometim } \\
\text { es } \\
\text { Occasion } \\
\text { ally } \\
\text { Frequentl } \\
\text { y } \\
\text { Always }\end{array}$ & $\begin{array}{l}95 \\
161 \\
288 \\
\mathbf{3 1 2}\end{array}$ & $\begin{array}{l}18.8 \\
33.6 \\
\mathbf{3 6 . 4}\end{array}$ \\
\hline $\begin{array}{l}\text { Evaluation of Alternatives based on Offers on } \\
\text { the product }\end{array}$ & $\begin{array}{l}\text { Never } \\
\text { Sometim } \\
\text { es } \\
\text { Occasion } \\
\text { ally } \\
\text { Frequentl } \\
\text { y } \\
\text { Always }\end{array}$ & $\begin{array}{r}15 \\
80 \\
176 \\
217 \\
\mathbf{3 6 8}\end{array}$ & $\begin{array}{r}1.7 \\
9.3 \\
20.6 \\
25.4 \\
\mathbf{4 3 . 0}\end{array}$ \\
\hline $\begin{array}{c}\text { Evaluation of Alternatives based on Ease of } \\
\text { Transaction }\end{array}$ & $\begin{array}{l}\text { Never } \\
\text { Sometim } \\
\text { es } \\
\text { Occasion } \\
\text { ally } \\
\text { Frequentl } \\
\text { y } \\
\text { Always }\end{array}$ & $\begin{array}{r}31 \\
85 \\
176 \\
203 \\
361\end{array}$ & $\begin{array}{r}3.6 \\
9.9 \\
20.6 \\
23.7 \\
\mathbf{4 2 . 2}\end{array}$ \\
\hline $\begin{array}{l}\text { Evaluation of Alternatives based on } \\
\text { Consumer Reviews }\end{array}$ & $\begin{array}{l}\text { Never } \\
\text { Sometim } \\
\text { es } \\
\text { Occasion } \\
\text { ally } \\
\text { Frequentl } \\
\text { y } \\
\text { Always }\end{array}$ & $\begin{array}{c}7 \\
96 \\
969 \\
208 \\
376\end{array}$ & $\begin{array}{l}19.7 \\
24.3 \\
43.9\end{array}$ \\
\hline $\begin{array}{c}\text { Evaluation of Alternatives based on Secure } \\
\text { Mode of Payment }\end{array}$ & $\begin{array}{l}\text { Never } \\
\text { Sometim }\end{array}$ & $\begin{array}{l}11 \\
56\end{array}$ & $\begin{array}{l}1.3 \\
6.5\end{array}$ \\
\hline
\end{tabular}




\begin{tabular}{|c|c|c|c|}
\hline & $\begin{array}{l}\text { es } \\
\text { Occasion } \\
\text { ally } \\
\text { Frequentl } \\
\text { y } \\
\text { Always }\end{array}$ & $\begin{array}{l}165 \\
\mathbf{4 5 6}\end{array}$ & $\begin{array}{l}19.6 \\
19.3 \\
\mathbf{5 3 . 3}\end{array}$ \\
\hline $\begin{array}{c}\text { Evaluation of Alternatives based on Past } \\
\text { online shopping experience }\end{array}$ & $\begin{array}{l}\text { Never } \\
\text { Sometim } \\
\text { es } \\
\text { Occasion } \\
\text { ally } \\
\text { Frequentl } \\
\text { y } \\
\text { Always }\end{array}$ & $\begin{array}{r}25 \\
57 \\
159 \\
\\
119 \\
496\end{array}$ & $\begin{array}{r}2.9 \\
6.6 \\
18.6 \\
13.9 \\
57.9\end{array}$ \\
\hline $\begin{array}{l}\text { Evaluation of Alternatives based on } \\
\text { Trustworthiness of online shopping websites }\end{array}$ & $\begin{array}{l}\text { Never } \\
\text { Sometim } \\
\text { es } \\
\text { Occasion } \\
\text { ally } \\
\text { Frequentl } \\
\text { y } \\
\text { Always }\end{array}$ & $\begin{array}{r}31 \\
56 \\
120 \\
209 \\
440\end{array}$ & $\begin{array}{r}3.6 \\
6.5 \\
14.0 \\
\end{array}$ \\
\hline $\begin{array}{l}\text { Evaluation of Alternatives based on } \\
\text { Discussion with family and friends }\end{array}$ & $\begin{array}{l}\text { Never } \\
\text { Sometim } \\
\text { es } \\
\text { Occasion } \\
\text { ally } \\
\text { Frequentl } \\
\text { y } \\
\text { Always }\end{array}$ & $\begin{array}{l}215 \\
152 \\
\mathbf{3 0 5}\end{array}$ & $\begin{array}{r}6.5 \\
15.0 \\
25.1 \\
\\
17.8 \\
35.6\end{array}$ \\
\hline
\end{tabular}

Source: Survey. The figures in Bold denote the highest percentage. 
Table 2

Mean and Standard Deviation of criteria for Evaluation of alternatives

\begin{tabular}{l|c|c|c}
\hline \multicolumn{1}{c|}{$\begin{array}{c}\text { Criteria for Evaluation of } \\
\text { Alternatives }\end{array}$} & Nea & Standard \\
Deviation
\end{tabular}




\section{Table 3}

KMO and Bartlett's Test for criteria for Evaluation of alternatives

\begin{tabular}{llc}
\hline Kaiser-Meyer-Olkin Measure of Sampling Adequacy. & 0.873 \\
& Approx. Chi-Square & 4524.003 \\
Bartlett's Test of Sphericity & df & 55 \\
& Sig. & 0.000 \\
\hline
\end{tabular}

Table 4

Communalities for criteria for Evaluation of Alternatives

\begin{tabular}{lcc}
\hline \multicolumn{1}{c}{ Criteria for Evaluation of Alternatives } & Initial & Extraction \\
\hline Price of Product & 1.000 & 0.225 \\
Quality of Product & 1.000 & 0.541 \\
Brand Name & 1.000 & 0.479 \\
Discounts and Deals & 1.000 & 0.718 \\
Offers & 1.000 & 0.780 \\
Ease of transaction & 1.000 & 0.530 \\
Consumer Reviews & 1.000 & 0.638 \\
Secure Mode of Payment & 1.000 & 0.677 \\
Past online shopping Experience & 1.000 & 0.752 \\
Trustworthiness of online shopping websites & 1.000 & 0.629 \\
Discussion with family and friends & 1.000 & 0.590 \\
\hline
\end{tabular}


Table 5

Total Variance of criteria for Evaluation of Alternatives

\begin{tabular}{|c|c|c|c|c|c|c|}
\hline \multirow{2}{*}{ Component } & \multicolumn{3}{|c|}{ Initial Eigen values } & \multicolumn{3}{|c|}{ Rotation Sums of Squared Loadings } \\
\hline & Total & $\%$ of Variance & Cumulative $\%$ & Total & $\%$ of Variance & Cumulative \% \\
\hline \multirow{2}{*}{1} & 5.23 & \multirow{2}{*}{47.557} & \multirow{2}{*}{47.557} & \multirow{2}{*}{3.371} & \multirow{2}{*}{30.647} & \multirow{2}{*}{30.647} \\
\hline & 1 & & & & & \\
\hline \multirow{2}{*}{2} & 1.32 & \multirow{2}{*}{12.068} & \multirow{2}{*}{59.625} & \multirow{2}{*}{2.759} & \multirow{2}{*}{25.084} & \multirow{2}{*}{55.731} \\
\hline & 8 & & & & & \\
\hline 3 & .924 & 8.398 & 68.023 & 1.352 & 12.292 & 68.023 \\
\hline 4 & .742 & 6.742 & 74.765 & & & \\
\hline 5 & .632 & 5.741 & 80.506 & & & \\
\hline 6 & .531 & 4.824 & 85.330 & & & \\
\hline 7 & .455 & 4.132 & 89.462 & & & \\
\hline 8 & .354 & 3.217 & 92.680 & & & \\
\hline 9 & .296 & 2.687 & 95.367 & & & \\
\hline 10 & .273 & 2.485 & 97.852 & & & \\
\hline 11 & .236 & 2.148 & 100.000 & & & \\
\hline
\end{tabular}

Table 6

Rotated Component Matrix of Criteria for Evaluation of Alternatives

\begin{tabular}{|c|c|c|c|}
\hline \multirow[b]{2}{*}{$\begin{array}{c}\text { Criteria for Evaluation of } \\
\text { Alternatives }\end{array}$} & \multicolumn{3}{|c|}{ Component } \\
\hline & $\begin{array}{c}1 \\
\text { Non-Product } \\
\text { Related } \\
\text { Criteria }\end{array}$ & $\begin{array}{c}\mathbf{2} \\
\text { Additional } \\
\text { Product Related } \\
\text { Criteria }\end{array}$ & $\begin{array}{c}3 \\
\text { Basic Product } \\
\text { Related } \\
\text { Criteria }\end{array}$ \\
\hline Price of Product & & & 0.917 \\
\hline Quality of Product & & & 0.501 \\
\hline Brand Name & & 0.653 & \\
\hline Discounts and Deals & & 0.834 & \\
\hline
\end{tabular}


ELK ASIA PACIFIC JOURNAL OF MARKETING \& RETAIL MANAGEMENT

ISSN 2349-2317 (Online); DOI: 10.16962/EAPJMRM/issn. 2349-2317/2018; Volume 9 Issue 4 (2018)

\begin{tabular}{l|l} 
Offers & 0.592 \\
Ease of transaction & 0.718 \\
Consumer Reviews & 0.717 \\
Secure Mode of Payment & 0.830 \\
Past online shopping & \\
Experience & 0.761 \\
Trustworthiness of online & \\
shopping websites & 0.765 \\
Discussion with family and & \\
friends &
\end{tabular}

